\title{
Effect of Supported Transition Metal Catalysts in NO Removal Reaction
}

\author{
MARZIEH HAMIDZADEH ${ }^{1,2}$, MITRA GHASSEMZADEH ${ }^{1 *}$, \\ ALIAKBAR TARLANI ${ }^{1}$ and SAEED SAHEBDEL FAR ${ }^{1}$

\begin{abstract}
${ }^{1}$ Catalyst Research Group, Petrochemical Research and Technology Company, National Petrochemical Company, Tehran, Iran.

${ }^{2}$ Chemistry and Chemical Engineering Research Center of Iran, Tehran, Iran. Corresponding author E-mail: m.ghassemzadeh@yahoo.de
\end{abstract}

http://dx.doi.org/10.13005/ojc/320155

(Received: December 22, 2015; Accepted: March 03, 2016)

\begin{abstract}
Selective catalytic reduction of nitrogen oxide with ammonia in the presence of excessive oxygen was investigated on transition metal oxides' catalysts ( $\mathrm{V}, \mathrm{Cr}, \mathrm{Mn}, \mathrm{Fe}$ ) supported on HZSM-5. Meanwhile, catalyst V/ZSM-5 and Fe/ZSM- 5 have shown the most activity and the conversion percentage of nitrogen oxides to nitrogen is more than $97 \%$ at temperatures above $300{ }^{\circ} \mathrm{C}$, in these two catalysts. All synthesized catalysts possessed a good stability. Analytical characterization of synthesized catalysts were conducted by different methods of temperature programmed reduction, absorption and desorption of nitrogen, temperature programmed desorption of ammonia, X-ray diffraction and diffuse reflectance UV-vis spectroscopy. The less the apparent activation energy is, the more their activity will be. Thus, the Cr/ZSM- 5 and V/ZSM- 5 catalysts showed the lowest and highest performance in this process, respectively.
\end{abstract}

Key words: Catalyst; Selective catalytic reduction; Manganese, Vanadium, Iron, Zeolite.

\section{INTRODUCTION}

The removal reaction of $\mathrm{NO}_{x}$ emissions is a major issue in recent decades to protect the environment ${ }^{1,2}$. Catalytic reaction of NH3-SCR (Selective catalytic reduction) is shown in the general equation $1^{3}$.

$$
4 \mathrm{NO}+4 \mathrm{NH}_{3}+\mathrm{O}_{2} \rightarrow 4 \mathrm{~N}_{2}+6 \mathrm{H}_{2} \mathrm{O}
$$

If along with $\mathrm{NO}, \mathrm{NO}^{2}$ exists in exhaust gas, the process will accelerate through the equation $(2)^{4}$.

$$
2 \mathrm{NO}+2 \mathrm{NO}_{2}+4 \mathrm{NH}_{3} \rightarrow 4 \mathrm{~N}_{2}+6 \mathrm{H}_{2} \mathrm{O}
$$

Nitrogen oxide emissions from vehicles are done by using the three-way catalysts from platinum family. Catalyst $\mathrm{V}_{2} \mathrm{O}_{5} / \mathrm{ZrO}_{2}$ with calcium promoter was effective in the removal of $\mathrm{NO}$ by $\mathrm{C}_{3} \mathrm{H}_{6} 5$. Studies 
showed that the catalysts of $\mathrm{V}_{2} \mathrm{O}_{5} / \mathrm{Ac}^{6}, \mathrm{~V}_{2} \mathrm{O}_{5} / \mathrm{CNTs}^{7}$, $\mathrm{V}_{2} \mathrm{O}_{5}-\mathrm{MnO}_{\mathrm{x}} / \mathrm{TiO}_{2}-\mathrm{C}^{8}, \mathrm{Mn}-\mathrm{Ce} / \mathrm{TiO}_{2}{ }^{9}, \mathrm{Ag}-\mathrm{V} / \mathrm{TiO}_{2}{ }^{10}$, $\mathrm{MnO}_{\mathrm{x}}{ }^{11}, \mathrm{MnO}_{2}-\mathrm{CeO}_{2}{ }^{12}, \mathrm{Mn} / \mathrm{TiO}_{2}{ }^{13,14}, \mathrm{Cr} / \mathrm{TiO}_{2}{ }^{15}$ and $\mathrm{Fe} / \mathrm{TiO}_{2}{ }^{16}$ have been examined beforehand. Results have shown that some of these catalysts indicate good activity in low temperature. The $\mathrm{V}_{2} \mathrm{O}_{5}-\mathrm{TiO}_{2}$ catalyst has shown that its superiority is largely due to acid sites which depend on the size of vanadium involved in the reaction ${ }^{17}$. Since zeolites have acidic structures, modification of their catalytic properties is carried out by transition metal ions in many chemical reactions. Zeolites as hosts of transition ions with the determined pore sizes inhibit or sinter the growth of nanoparticles of cation at high temperatures. During the last decade, the catalysts based on zeolite indicated a perfect process for this reaction. Cu-Zn / ZSM-5 ${ }^{18}$, Cu-Fe / ZSM-5 ${ }^{19} \mathrm{Cu} / \mathrm{ZSM}-5^{20}$ are among the investigated catalysts which have a high capability for the removal of $\mathrm{NO}_{\mathrm{x}}$. The previous studies have mainly focused on the changes of the active component, synthesis and calcination temperature. Therefore, the impact of active component's changes on the nitrogen oxide removal reaction with ammonia reduction and excessive oxygen was studied. Cations selected from the first row transition metals consist of chromium, vanadium, manganese and iron and its base is ZSM-5 zeolite. Catalysts were prepared by ion exchange with chloride salts of the metals. In addition to the reactor test, the apparent activation energy for each of the catalysts has been calculated and then the catalyst characterization analysis has been performed.

\section{RESULTS AND DISCUSSION}

\section{FTIR results}

First, in Figure 1, catalysts containing vanadium, chromium, manganese and iron were compared with each other. Characteristic vibration bands were identified for $\mathrm{H}-\mathrm{ZSM}-5$ in the vicinity of wavelengths of $456,554,791$ and $1100 \mathrm{~cm}^{-1}$ in the sample ZSM-5; the bands of 1100,791 and $1456 \mathrm{~cm}^{-1}$, were allocated to asymmetric bond stretching $\mathrm{O}-\mathrm{Si}-\mathrm{O}$, symmetric stretching and vibration bonds $\mathrm{T}-\mathrm{O}$, respectively, within the tetrahedral network. In addition, peak in the range of $1547 \mathrm{~cm}^{-1}$ belongs to five double rings in the network ${ }^{22-23}$. Vibration area location of $790 \mathrm{~cm}^{-1}$ to $802 \mathrm{~cm}^{-1}$ is important in determining the amount of aluminum structure (QFAl) of zeolite.
According to the FTIR spectrum and the o vibration (about cm-1 790) the value of QFAI (mg Al atoms / $\mathrm{g}$ zeolite) was calculated from equation (4).

$$
Q_{F A l}=(802.5-v 2) / 9.76
$$

In these spectra, the increase in the intensity of the $1100 \mathrm{~cm}^{-1}$ absorption band, Si-OT asymmetric stretching vibration band occur simultaneously with transition metals' doped ions; this is a sign to remove aluminum from the zeolite and reduce the amount of QFAl and increase the Si / Al ratio. Changes in catalysts' peaks with precursor of nitric acid were less. Also, the vibrational bands at $1223 \mathrm{~cm}^{-1}$ is assigned to the external connections of $\mathrm{TO}_{4}$ tetrahedrons ${ }^{24-25}$ which was observed in all catalysts. Bands of 1634 $\mathrm{cm}^{-1}$ are assigned to the bending vibration of zeolite water molecules. Two bands of 3226 and $3637 \mathrm{~cm}$ ${ }^{1}$ are attributed to $\mathrm{OH}$ stretching vibration and Bands around 3,600 to $3500 \mathrm{~cm}^{-1}$ belong to the Brønsted acidic conditions ${ }^{25}$. As a result, it is attributed to bonding of the metal ion with $\mathrm{OH}(\mathrm{M}-\mathrm{OH}$ and $\mathrm{Al}-\mathrm{OH}$, respectively). A wide Band has appeared in the initial zeolite in this area. Weak Bands in 3750 to 3900 $\mathrm{cm}^{-1}$ related to the end silanol has appeared in all of synthetic catalysts. Absorption bands in $2020 \mathrm{~cm}^{-1}$ in all IR spectrum are resulted from $\mathrm{H}$-Si vibration or silicon impurities in the zeolite's structure ${ }^{26-28}$. It is expected that polyvanadate stretching vibration in $870 \mathrm{~cm}^{-1}$ and characteristic vibration of $\mathrm{V}_{2} \mathrm{O}_{5}$ in 452 , $475,526,696$ and $996 \mathrm{~cm}^{-1}$ appear but none of them were found in the range of the catalyst. A minor shift in the vibrational bands is observed to the zeolite mother, which is a sign of good vanadium distribution on the base. The stretching vibration mode of metal oxygen for the catalysts Mn / ZSM-5 and Fe / ZSM-5 is 623 and 400 to $780 \mathrm{~cm}^{-1}$, respectively, and overlaps with the vibrations of the zeolite.

As shown in Figure 1, the slight shift in the bars and a change in their intensity are observed in the catalysts containing $\mathrm{Mn}, \mathrm{Cr}$ and $\mathrm{V}$ compared to zeolite; the results indicate that QFAI in the catalyst increases in the following order.

Mn / ZSM-5 <Fe / ZSM-5 <V / ZSM- 5 <Cr / ZSM- 5 <ZSM-5

Therefore, the amount of aluminum removal is higher in the presence of chromium and iron. 
Temperature programmed reduction

TP $R$ curve is shown in Figure 2. Profile catalyst Mn / ZSM-5 in less than $570^{\circ} \mathrm{C}$ indicates four peaks that are mutually overlapping and are centered in 425 and $536^{\circ} \mathrm{C}$ which is allocated to reduction of $\mathrm{MnO}_{2}$ to $\mathrm{MnO}$ through transmissions of $\mathrm{Mn}_{2} \mathrm{O}_{3}$ and $\mathrm{Mn}_{3} \mathrm{O}_{4}$. The peaks compared to the reduction of $\mathrm{MnO}_{2}$ pure crystals appear at higher temperatures which are due to the high distribution of manganese in the base phase ${ }^{29}$. Peak reduction of $\mathrm{Fe}_{2} \mathrm{O}_{3}$ to $\mathrm{FeO}$ in the sample $\mathrm{Fe} / \mathrm{ZSM}-5$ only indicates a maximum of $390^{\circ} \mathrm{C}$.

In the TPR curve of catalyst V / ZSM-5, only a wide peak is observed at 390 to $650^{\circ} \mathrm{C}$, which even in comparison with pure pentoxide vanadium, peak reduction has started at higher temperatures. Since the location of metal oxide in different sites, the structures of zeolite on its surface or in meso pores is possible, and ease of metal ions' reduction in each of the positions is different; thus, generally, reduction peaks are not beam and narrow ${ }^{30}$. When the distribution of metal ions in zeolite is high, the connection between two metal ions and the surface occurs after the failure of $\mathrm{M}-\mathrm{O}-\mathrm{M}$ bonds in doped compounds and bond formation with Si or Al zeolite. The formation of new bonds in the structure of zeolite is confirmed with the changes of the location of metal oxide reduction peaks in the synthesis catalyst of the pure metal oxide and vibration displacement of these small bands fewer than $1200 \mathrm{~cm}^{-1}$ in the FTIR compared to the higher frequencies in the mother zeolite. Reduction peak at 370 and in $270^{\circ} \mathrm{C}$ are related to the reduction of $\mathrm{Cr}^{6+}$ to $\mathrm{Cr}^{3+}$ in the $\mathrm{Cr}$ / ZSM- 5 catalyst ${ }^{31}$.

\section{Absorption and desorption of nitrogen}

Textural properties of catalyst including specific surface area, micro pore volume, mean size of pore, total pore volume and the external surface are shown in Table 1. As it is shown, the mean pore size in the mother zeolite is $1.77 \mathrm{~nm}$ and vanadium has no effect on the mean pore size. The effect of manganese, chromium and iron $(3.6 \mathrm{~nm})$ is negligible. Radii of metal ions doped from $3 \mathrm{~d}$ row to $\mathrm{Al}^{3+}$ are near so changes in the pore volume is

Table 1: Comparison of nitrogen absorption and desorption of catalysts M / ZSM-50 (M = V, Cr, Mn, Fe)

\begin{tabular}{lcccccc}
\hline Component & $\mathbf{S}_{\text {BET }}\left(\mathbf{m}^{2} / \mathbf{g}\right)$ & $\mathbf{S}_{\text {ext }}\left(\mathbf{m}^{2} / \mathbf{g}\right)$ & $\mathbf{V}_{\text {MP }}{ }^{*}\left(\mathbf{c m}^{3} / \mathbf{g}\right)$ & $\mathbf{S}_{\text {MP }}\left(\mathbf{m}^{2} / \mathbf{g}\right)$ & $\mathbf{S}_{\text {MP }} / \mathbf{S}_{\text {BET }}$ & $\mathbf{S}_{\text {ext }} / \mathbf{S}_{\text {BET }}$ \\
\hline V/ZSM-5 & 195 & 11 & 0.10 & 184 & 95 & 5 \\
V/ZSM-5 A & 175 & 12 & 0.08 & 163 & 93 & 7 \\
Cr/ZSM-5 & 292 & 16 & 0.14 & 276 & 94 & 5.5 \\
Mn/ZSM-5 & 327 & 19 & 0.15 & 308 & 94 & 6 \\
Fe/ZSM-5 & 281 & 55 & 0.11 & 226 & 81 & 20 \\
ZSM-5 & 348 & 34 & 0.17 & 314 & 90 & 10 \\
ZSM-5/A & 292 & 18 & 0.13 & 274 & 94 & 6 \\
\hline
\end{tabular}

A: After reactor; MP: Micro Pore

Table 2: Comparison of XRD results of catalyst $\mathrm{M} / \mathrm{ZSM}-50(\mathrm{M}=\mathrm{V}, \mathrm{Cr}, \mathrm{Mn}, \mathrm{Fe})$

\begin{tabular}{lcccccc}
\hline $\begin{array}{l}\text { Crystallite } \\
\text { Size }(\mathbf{n m})\end{array}$ & $\begin{array}{c}\text { Density } \\
\mathbf{g} / \mathbf{c m}^{3}\end{array}$ & $\begin{array}{c}\text { Volume } \\
\AA^{3}\end{array}$ & $\mathbf{c}$ & $\mathbf{b}$ & $\mathbf{a}$ & \\
\hline 59 & 1.92 & 5227.78 & 13.4468 & 19.3498 & 20.092 & ZSM-5 \\
57.9 & 1.88 & 5348 & 13.3406 & 20.1225 & 19.922 & V/ZSM-5 \\
67.9 & 1.86 & 5423.18 & 13.4168 & 20.152 & 20.058 & $\mathrm{Mn} / \mathrm{ZSM}-5$ \\
61.8 & 1.86 & 5416.53 & 13.3913 & 20.1394 & 20.08414 & $\mathrm{Fe} / \mathrm{ZSM}-5$ \\
70 & 1.86 & 5415.931 & 13.6065 & 20.2044 & 19.7006 & Cr/ZSM-5 \\
& 1.89 & 5322.57 & 13.352 & 19.884 & 20.048 & Standard \\
\hline
\end{tabular}


Table 3: Comparison of the activation energy of catalysts $M$ I ZSM-50 ( $M=\mathrm{Cr}, \mathrm{V}, \mathrm{Mn}, \mathrm{Fe}$ )

\begin{tabular}{lc}
\hline Samples & $\mathbf{E}_{\text {act }}(\mathrm{Kcal} / \mathrm{mol})$ \\
\hline $\mathrm{V}(\mathrm{Cl}) / \mathrm{ZSM}-5$ & 23. \\
$\mathrm{Mn}(\mathrm{Cl}) / \mathrm{ZSM}-5$ & 24.8 \\
$\mathrm{Cr}(\mathrm{Cl}) / \mathrm{ZSM}-5$ & 35.9 \\
$\mathrm{Fe}(\mathrm{Cl}) / \mathrm{ZSM}-5$ & 23.2 \\
\hline
\end{tabular}

$E_{\text {act }}$ : Apparent activation energy

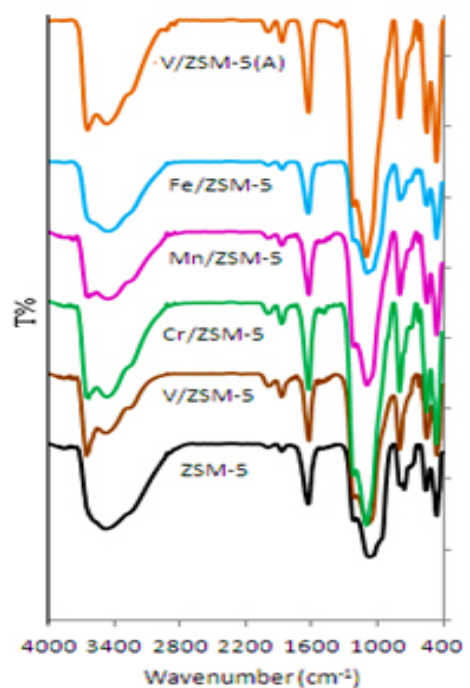

Fig. 1: The FTIR spectrum

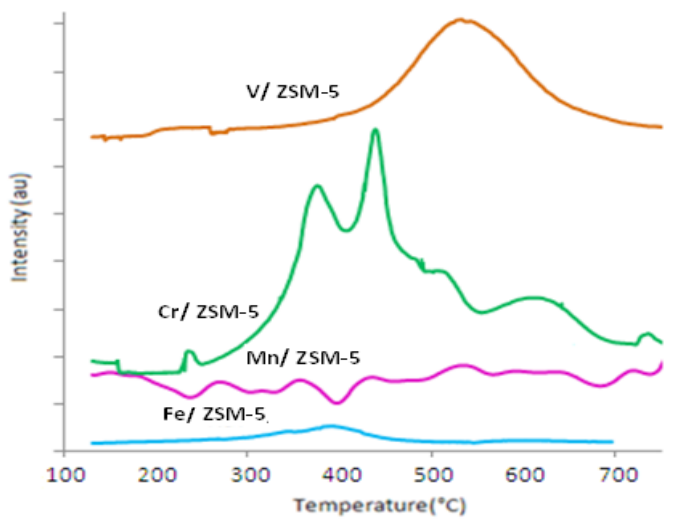

Fig. 2: Comparison of temperature programmed reduction curve of'catalysts $M$ / ZSM-5 (M = Fe, Cr, V, Mn) low. BET surface area of all catalysts to the mother zeolite has decreased, the external surface in the catalyst Mn / ZSM-5 has significantly increased which is a sign is the increased meso positions. This fact corresponds to the location of doped metal oxide on the surface of zeolite and not in the channels and pores, the aluminum ions' migration to external structure and formation of aluminum oxide. Sometimes by the leaching of aluminum from the frame, silicon becomes amorphous so the reduction of $Q_{F A L}$ is possible in the zeolite and this matches the absence of strong acid position in Mn / ZSM-5. Nitrogen's desorption and absorption isotherm curve on all catalysts is of type I, which represents the structure of microspores.

Major peaks in ${ }^{\circ} 9 / 23,{ }^{\circ} 9 / 8,{ }^{\circ} 94 / 7=2$ è (JCPDS Card No: 049-0657) are the characteristics of ZSM-5 and $6.2^{\circ}, 26.3^{\circ}=2$ è (JCPDS Card No: 46-1045) are the characteristics of quartz. After the placement of the active component, in XRD structures, the peaks of ZSM- 5 and the crystalline structure reduce and this reduction in crystallization occurs with the decrease in the micropores and all pores of the catalyst to ZSM-5; and alters the ratio of $\mathrm{Si} / \mathrm{Al}$ to the framework of zeolite. Size of crystals in catalysts V / ZSM-5, Fe / ZSM-5, Zn / ZSM-5, Cr / ZSM-5, is $57.9 \mathrm{~nm}, 61.8,67.9$ and 70, respectively, showing small changes. Calculation of unit cell in the orthorhombic structure are shown in Table 2. According to the Table, unit cell size in the catalysts between increases between $2.3 \%$ to $3.7 \%$. Crystallinity of catalysts was calculated according to XRD using the main line 23.9; the results show

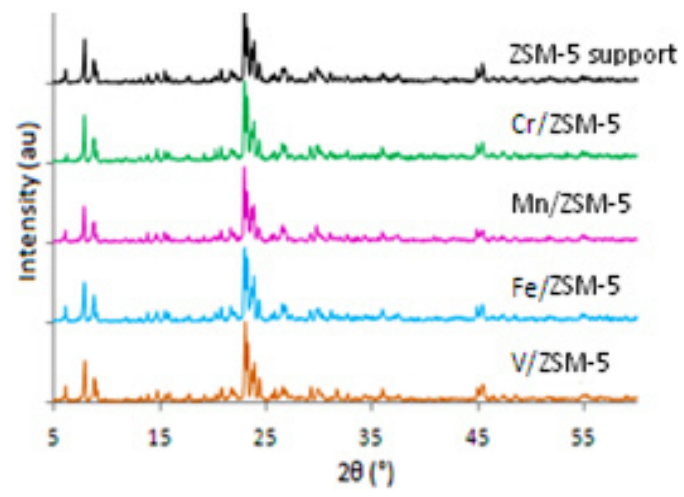

Fig. 3: Shows the XRD spectrum of catalysts containing vanadium, chromium, iron and manganese based on ZSM-5 
that the crystallinity of $\mathrm{Cr} / \mathrm{ZSM}-5$ increases when comparing with mother zeolite. This means that some of the atoms of Si or Al have been transformed into crystalline form from the amorphous initial compounds. Decrease in crystallinity in other catalysts is due to the leaching of the aluminum to the external sides of the structure and the filling of the pores by silica.

\section{Thermal programmed desorption of ammonia}

Two peaks are mainly observed in zeolites; one at a low temperature and the other at a high temperature in NH3-TPD. Since the zeolite sample is acidic and possess high crystallinity, the number of molecules of ammonia desorbed at high temperature are proportional to the number of atoms of aluminum in zeolites. Ammonia which is desorbed at low temperatures, is mainly absorbed on metal cation, while in $\mathrm{H}$ form or shape of the acidic zeolite, $\mathrm{NH} 3$ is absorbed on Bronsted acid sites and $\mathrm{NH}_{4}{ }^{+}$. The driving force behind this kind of absorption is mainly based on the electrostatic interactions between the sites of ion exchange and $\mathrm{N}-\mathrm{H}$ bonds. The interaction of water molecules with such status (hydrogen bonding) is stronger than the interaction of ammonia, because the polarity of $\mathrm{O}-\mathrm{H}$ in water is more than $\mathrm{N}-\mathrm{H}$ of Ammonia, so this type of ammonia are replaced with water. Thus, low temperature peak has no solid acidic properties on the $\mathrm{H}$ zeolite. In other words, the ammonia that remains after the water evaporation must interact with acidic sites, because the amount of ammonia is more than water. While ammonia is absorbed on the Brønsted acid sites, it can also absorb on the sites of Al or Al outside the structure

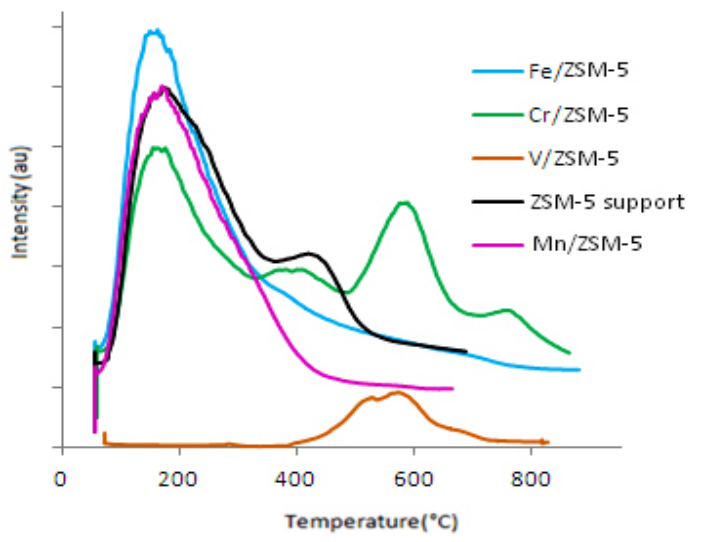

Fig. 4: The spectrum of TPD-NH3 of catalysts M / ZSM-5 (M = Cr, V, Fe, Mn) of zeolites. When the ammonia is adsorbed on the solid acid (ions with high loads and low beam) due to the strong interaction at a higher temperature desorption is occurred; so in the catalyst containing $+\mathrm{Cr} 6$, we expect the high temperature desorption peak to have more intensity. Figure 4 . indicates the analysis Chart of TPD- $\mathrm{NH}_{3}$ catalyst containing chromium, vanadium, manganese and iron; these catalysts showed three acidic positions of weak, average and strong. Strong acidic sites -higher than ${ }^{\circ}$ C300- are observed in the catalyst having vanadium and chromium and zeolite and desorption peaks in the other catalyst is observed in the range of 150 to $180^{\circ} \mathrm{C}$. Accordingly, there wasn't any strong acidic site in Mn / ZSM-5, while in the V / ZSM-5 weak acid positions were disappeared and the number of very strong acid sites increased. Fe / ZSM-5 consists of two overlapping peaks, and is placed in the weak acidic and relatively strong acidic positions and $\mathrm{Cr}$ / ZSM-5 catalyst contains weak, moderate, strong and very strong positions.

\section{UV spectrum (DRS-UV-Vis)}

The solid state UV Spectrum (reflective penetration) catalysts of $\mathrm{M} / \mathrm{ZSM}-5(\mathrm{M}=\mathrm{V}, \mathrm{Cr}, \mathrm{Mn}$, $\mathrm{Fe}$ ) are shown in Figure 5. In the catalyst $\mathrm{V} / \mathrm{ZSM}-5$, the location of transfer band's load of oxygen and vanadium depend on the number of oxygen around central vanadium ion atoms (symmetry). Several arrangements are possible for $\mathrm{VO}_{\mathrm{x}}$. If the $\mathrm{VO}_{\mathrm{x}}$ is tetrahedral, the absorption band appears in $240 \mathrm{~nm}$, while for the arrangements of square pyramid and octahedron, absorption is expected in 340 and 410 $\mathrm{nm}$ respectively. Based on the spectrum of sample $\mathrm{V} / \mathrm{ZSM}-5$, most of the $\mathrm{VO}_{\mathrm{x}}$ varieties are distorted in the tetragonal symmetry (band around $256 \mathrm{~nm}$ ) ${ }^{33}$.

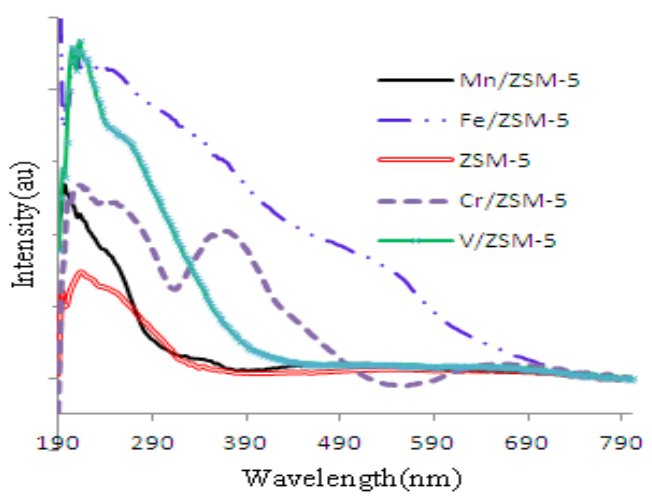

Fig. 5: UV-Vis spectrum of catalysts M / ZSM-5 (M = Cr, V, Fe, Mn) 


\section{UV spectrum (DRS-UV-Vis)}

The solid state UV Spectrum (reflective penetration) catalysts of $\mathrm{M} / \mathrm{ZSM}-5(\mathrm{M}=\mathrm{V}, \mathrm{Cr}, \mathrm{Mn}$, $\mathrm{Fe}$ ) are shown in Figure 5. In the catalyst V / ZSM-5, the location of transfer band's load of oxygen and vanadium depend on the number of oxygen around central vanadium ion atoms (symmetry). Several arrangements are possible for $\mathrm{VO}_{\mathrm{x}}$. If the $\mathrm{VO}_{\mathrm{x}}$ is tetrahedral, the absorption band appears in $240 \mathrm{~nm}$, while for the arrangements of square pyramid and octahedron, absorption is expected in 340 and 410 $\mathrm{nm}$ respectively. Based on the spectrum of sample V/ZSM-5, most of the $\mathrm{VO}_{x}$ varieties are distorted in the tetragonal symmetry (band around $256 \mathrm{~nm}$ ) ${ }^{33}$.

Two types of electron capture are seen in the catalyst Fe / ZSM-5; the first one in the region of 400 to $600 \mathrm{~nm}$ with maximum is attributed to 554 $\mathrm{nm}$ the ligand field ${ }^{4} \mathrm{~T}_{2}(4 \mathrm{G})$ '! $^{6} \mathrm{~A}_{1} \mathrm{Fe}^{3+}$ high spin. The second one is in the 360 to $380 \mathrm{~nm}$ related to load transfer from ligand to the metal ${ }^{33}$. Maxima observed in the 356 and nm495 are attributed to $\mathrm{Fe}_{2} \mathrm{O}_{3}{ }^{34}$. The presence of MnO in Mn / ZSM-5 is confirmed because of the wide absorption in $506 \mathrm{~nm}$ and is related to the transfers of ${ }^{4} \mathrm{~T}_{1 \mathrm{~g}}(4 \mathrm{G})$ '! ${ }^{6} \mathrm{~A}_{1 \mathrm{~g}}(\mathrm{~S})$. Three bands of 330,490 and $790 \mathrm{~nm}$ are related to the transfer of dd in $\mathrm{Mn}_{2} \mathrm{O}_{3}$ varieties ${ }^{35-37}$. The two bands of $212,252 \mathrm{~nm}$ in catalyst $\mathrm{Cr} / \mathrm{ZSM}-5$ belong to $\mathrm{Cr}^{3+}$ in $\mathrm{Cr}_{2} \mathrm{O}_{3}$, and two bands of 374 and $605 \mathrm{~nm}$ re related to the CrOx clusters. UV-Vis spectra of metal oxides are similar to M / ZSM-5 of each ion so there were no significant geometry deviations after their placement on the base.

\section{Reactor test of M / ZSM-5 Catalysts}

The activities of M / ZSM-5 ( $\mathrm{M}=\mathrm{Mn}, \mathrm{V}, \mathrm{Cr}$, $\mathrm{Fe}$ ) catalysts at 200 to $360^{\circ} \mathrm{C}$ is shown in Figure 6

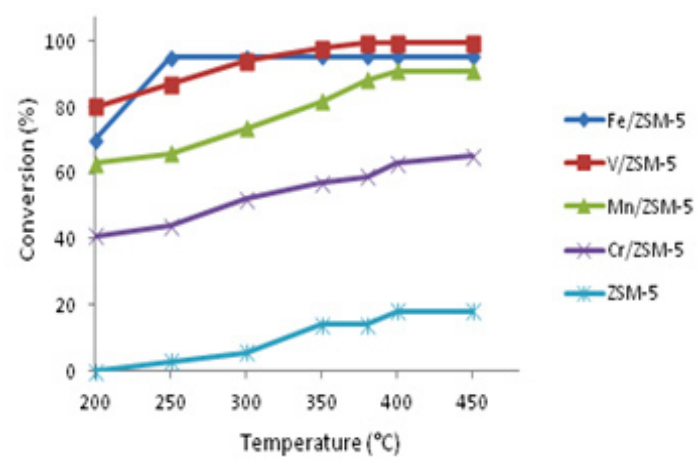

Fig. 6: The activity of catalysts M / ZSM-5 ( $\mathrm{M}=\mathrm{Cr}, \mathrm{V}, \mathrm{Mn}, \mathrm{Fe}$ ) at 200 to $450^{\circ} \mathrm{C}$ for removing reactions of NO. A chromium catalyst is not appropriate for this reaction and the increase in temperature of all catalysts causes an increase in their activity, then they reach to a maximum. Only the catalyst Fe / ZSM-5 indicates a mild negative change in slope, after reaching a maximum of $97 \%$ in $250^{\circ} \mathrm{C}$.

Table 3 shows the apparent activation energy of the reaction by varying the temperature from 200 to $400^{\circ} \mathrm{C}$. Two catalysts of Mn /ZSM- 5 and V/ ZSM- 5 have had the lowest activation energy and the highest activation energy. Value of the apparent activation energy on HZSM-5 $(55 \mathrm{~kJ} / \mathrm{mol})$ is much less (38), but with the values of 2.7 to $9 \mathrm{~kJ} / \mathrm{mol}$, it has allocated higher amounts compared with other researches (39).

According to Figure 7. Catalysts were stable for 24 hours at a constant temperature of $360^{\circ} \mathrm{C}$; the best results belong to catalysts containing iron or vanadium.

\section{Experimental section \\ Preparation of catalyst}

The ZSM-5 zeolite was purchased from Zeolyst Co. with the $\mathrm{SiO}_{2} / \mathrm{Al}_{2} \mathrm{O}_{3}$ ratio of 40 with an area of $348 \mathrm{~m}^{2} / \mathrm{g}$. The zeolite was then added to a $0.2 \mathrm{M}$ saline solution of manganese-, chromium-, vanadium-, or iron chloride. The slurry was stirred for 15 minutes, then transferred to a static reactor of acetyl with a Teflon coating, and finally placed in a $60^{\circ} \mathrm{C}$ oven for two hours. The resulting sample was washed with deionized water, dried in an oven at $150^{\circ} \mathrm{C}$ for 12 hours, and calcinated in a furnace at $480^{\circ} \mathrm{C}$ for 4 hours. The furnace's temperature elevation rate was $3^{\circ} \mathrm{C} / \mathrm{min}$.

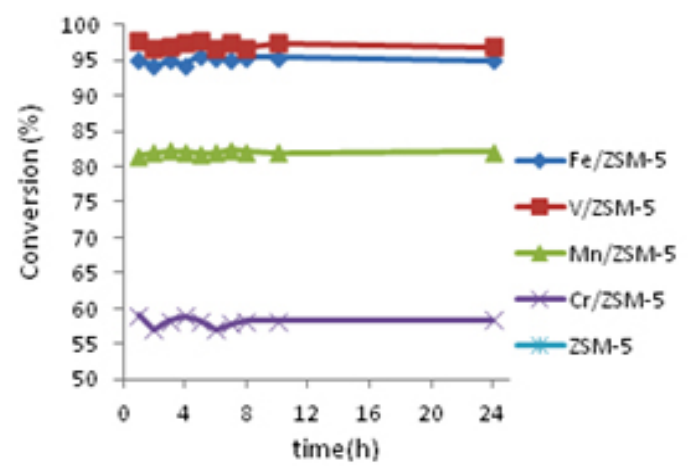

Fig. 7: Catalysts. M / ZSM-5 $(\mathrm{M}=\mathrm{Cr}, \mathrm{V}, \mathrm{Mn}, \mathrm{Fe})$ at $360^{\circ} \mathrm{C}$ 


\section{Characterization of the catalyst}

The surface area, total pore volume, external surface area, the volume of micropores, and the mean size of pores were measured through the nitrogen absorption and desorption isotherm at $77 \mathrm{~K}$ within the relative pressure range $\left(\mathrm{P} / \mathrm{P}_{0}\right)$ of 0.04-0.99 using a nitrogen absorption analyzer, the Quantochrom Nova 2000. Before measurement, all of the samples were degasified for three hours at $150^{\circ} \mathrm{C}$ for 3 hours. The area of the total surface area and the external surface was obtained using the BET method and t-method, respectively. The total volume of the pores was obtained from the volume of the desorbed nitrogen at the relative pressure of 0.99 . The mean size of the pores was also determined based on the desorption data using the BJH method.

The x-ray diffraction pattern(XRD) of the samples was recorded with a Philips diffractometer, using CuKá radiation ( $\mathrm{e}=1.54050 \AA$ ) within the angle range of 2 è from 4 to $89^{\circ}$, followed by identification of the crystal phase using the files of the Joint Committee on Powder Diffraction Standards (JCPDS). The Scherer equation was used to obtain the size of the crystals. Based on the distance between the lines and the orthorhombic crystal structure in the ZSM-5 zeolite as the main phase, the dimensions of the unit cell and its volume were calculated.

The temperature-programmed reduction (TPR) and ammonium temperature-programmed desorption tests were carried out using a BELCAT A with a TCD detector; its heating rate was programmable within the range of 25 to $1000^{\circ} \mathrm{C}$. For the TPR test, around $50 \mathrm{mg}$ of the samples was heated in an argon atmosphere with the flow rate of $50 \mathrm{~cm}^{3} \mathrm{~g}^{-1}$ for two hours at $150^{\circ} \mathrm{C}$. Next, the temperature was raised from 150 to $800^{\circ} \mathrm{C}$ under a flow of $5 \%$ of $\mathrm{H}_{2}$ in $\mathrm{Ar}$ with the same flow rate of $50 \mathrm{~cm}^{3} \mathrm{~g}^{-1}$. Then it was fully reduced at this temperature.

In order to determine the number of acidic sites and the acidic power of the catalysts, TPD$\mathrm{NH}_{3}$ analysis was performed on each catalyst. First, about $100 \mathrm{mg}$ of the sample was heated in a helium atmosphere with a flow rate of $50 \mathrm{~cm}^{-3} \mathrm{~g}^{-1}$ for one hour at $300^{\circ} \mathrm{C}$. Next, it was cooled down to $60^{\circ} \mathrm{C}$, and then saturated with ammonium for one hour under the flow of $2.5 \% \mathrm{NH}_{3} / \mathrm{He}$. Finally, physically absorbed ammonium desorption was carried out by first passing helium over the catalyst surface for $30 \mathrm{~min}$, then by increasing the temperature at a rate of $10^{\circ} \mathrm{C} \mathrm{min} \mathrm{m}^{-1}$ to $700^{\circ} \mathrm{C}$, causing the desorption to occur.

To study the influence of electron transfer, the diffuse reflectance UV-visible spectroscopy (Shimadzu Company) was used.

To identify the structural vibrations, the level of crystallinity of the structure, and the amount of aluminum available within the hydrated zeolite framework $\left(Q_{F A L}\right), F T I R$ analysis was used. The level of crystallinity for the zeolites with an MFI structure was calculated by the following equation (1):

\%Crystallinity from IR=(I_540/I_450*100)/0.72

The FTIR analyzer device, Bruker Vertex 80 model, was equipped with a MCT-NB mercury cryogenic detector.

\section{Catalyst efficiency test}

The catalyst activity test was carried out on $2 \mathrm{~g}$ of the catalyst by a selective catalytic reduction (SCR) reaction of nitrogen oxide in the presence of ammonia and excessive oxygen on an Inconel-800 fixed bed reactor with an internal diameter of $9 \mathrm{~mm}$. The feed compound contained $2.6 \% \mathrm{O}_{2}, 350 \mathrm{ppm}$ $\mathrm{NH}_{3}, 350$ ppm NO, with the remaining balance being nitrogen. The gas hourly space velocity (GHSV) was $30000 \mathrm{~h}^{-1}$ and the conversion percentage was determined using a gas analyzer, the Testo 340 , as a function of time and temperature $\left(200\right.$ to $\left.400^{\circ} \mathrm{C}\right)$. The catalytic activity was calculated using equation (1):

$\mathrm{NO}_{\mathrm{x}}$ conversion $=\left(\right.$ inlet $\mathrm{NO}_{\mathrm{x}}(\mathrm{ppm})$ " outlet $\mathrm{NO}_{x}$ $(\mathrm{ppm}) \times 100)$ /inlet NOx $(\mathrm{ppm})$

Calculation of the activation energy was conducted using the Arrhenius relation at a low temperature. 


\section{CONCLUSIONS}

1. In the selective catalytic reduction reaction with ammonia, the catalysts Fe / ZSM- 5 and V / ZSM-5 indicated the lowest apparent activation energy.

2. Two catalysts of Fe / ZSM-5 and V / ZSM-5 indicated a conversion percentage higher than $97 \%$ for the conversion of $\mathrm{NO}$ to nitrogen; so the possibility of replacement of iron instead of vanadium for the reaction is valid in the industry.

3. Decreasing in the apparent activation energy creates increasing the activity of the catalyst.

4. Crystallinity is reduced in all catalysts when comparing with mother zeolite, except for $\mathrm{Cr}$ / ZSM-5 catalyst.

\section{REFERENCES}

1. Kang, W ; Choi, . B; Thermo-diffusion, diffusion-thermo and chemical reaction effects on MHD flow of viscous fluid in divergent and convergent channels Chem. Eng. Sci., 2016, 141, 175-183.

2. Li, S.; Hao, Q.; Zhao, R.; Liu, D.; Duan, H.; Dou, B. ; Highly efficient catalytic removal of ethyl acetate over $\mathrm{Ce} / \mathrm{Zr}$ promoted copper/ ZSM-5 catalysts. Chem. Eng. J., 2016, 285, 536-543.

3. Koebel, M., and Strutz, E. O., "Thermal and hydrolytic decomposition of urea for automotive selective catalytic reduction systems: thermochemical and practical aspects, Ind. Eng. Chem.Res., 2003, 42, 2093- 2100.

4. Devadas, M., Kröcher, O., Elsener, M., Wokaun, A., Söger, N., Pfeifer, M., Demel, Y., Mussmann, L., Influence of $\mathrm{NO}_{2}$ on the selective catalytic reduction of $\mathrm{NO}$ with ammonia over Fe ZSM5, Appl. Catal., B., 2006, 67, 187- 196.

5. Ohno, T.; Tanaka, E.; Hatayama, F.; Toda Y.; Miyata, $\mathrm{H}$.; Promoting effect of $\mathrm{Pt}$ addition to $\mathrm{V}_{2} \mathrm{O}_{5} / \mathrm{ZrO}_{2}$ catalyst on reduction of $\mathrm{NO}$ by $\mathrm{C}_{3} \mathrm{H}_{6}$ , Catal. Let. 2001, 77(4) 183-187.

6. Zhu Z; Liu Z.; Liu S.; Niu H. Catalytic NO reduction with ammonia at low temperatures on $\mathrm{V}_{2} \mathrm{O}_{5} / \mathrm{AC}$ catalysts: effect of metal oxides addition and $\mathrm{SO}_{2}$ Appl Catal B, 2001, 30:267276.

7. Huang B., Huang R, Jin D., Ye D. Low temperature $\mathrm{SCR}$ of $\mathrm{NO}$ with $\mathrm{NH}_{3}$ over carbon nanotubes supported vanadium oxides, Catal Today. 2007, 126, 279-283.

8. Li Q.; Yang H.; Nie A.; Fan X.; Zhang X.; Catalytic Reduction of $\mathrm{NO}$ with $\mathrm{NH}_{3}$ over $\mathrm{V}_{2} \mathrm{O}_{5}$ $\mathrm{MnO}_{\mathrm{X}} / \mathrm{TiO}_{2}$-carbon nanotube composites
Catal Lett. 2011, 141:1237-1242.

9. Jin R.; Liu Y.; Wu Z.; Wang H.; Gu T.; Lowtemperature selective catalytic reduction of $\mathrm{NO}$ with $\mathrm{NH}_{3}$ over $\mathrm{Mn}-\mathrm{Ce}$ oxides supported on $\mathrm{TiO}_{2}$ and $\mathrm{Al}_{2} \mathrm{O}_{3}$ : A comparative study, Chemosphere 2010, 78,1160-1166.

10. Zaihua W.; Xinjun L.; Wenji S.; Jinfa C.; Tao L.; Ziping F. Promotional effect of Ag-doped Ag-V/ $\mathrm{TiO}_{2}$ catalyst with low vanadium loadings for selective catalytic reduction of $\mathrm{NO}_{x}$ by $\mathrm{NH}_{3}$. Reac Kinet Mech Cat , 2011, 103 : 353-365.

11. Tang X, Hao J, Xu W, Li J , Low temperature selective catalytic reduction of $\mathrm{NO}_{x}$ with $\mathrm{NH}_{3}$ over amorphous $\mathrm{MnO}$ catalysts prepared by three methods. Catal Commun ,2007, 8: 329334.

12. Qi G.; Yang R.; Characterization and FTIR Studies of $\mathrm{MnO}_{x}$ " $\mathrm{CeO}_{2}$ Catalyst for LowTemperature Selective Catalytic Reduction of $\mathrm{NO}$ with $\mathrm{NH}_{3}$, J Phys Chem B ,2004, 108(40) 15738-15747.

13. Smirniotis P.G.; Sreekanth P.M.; Pena D.A.; Jenkins R.G.; Manganese oxide catalysts supported on $\mathrm{TiO}_{2}, \mathrm{Al}_{2} \mathrm{O}_{3}$, and $\mathrm{SiO}_{2}$ : $\mathrm{A}$ comparison for low-temperature SCR of NO with $\mathrm{NH} 3$, Ind Eng Chem Res . 2006, 45, 6436-6443.

14. Wang T.Y.; Sun K; Lu Z.; Zhang Y.J.; Low temperature $\mathrm{NH}_{3}-\mathrm{SCR}$ reaction over $\mathrm{MnO}_{x}$ supported on protonated titanate, React Kinet Mech Catal , 2010, 101:153-161.

15. Schneider H, Maciejewski M, Kohler K, Wokaun A, Baiker A Chromia Supported on Titania: VI. Properties of Different Chromium Oxide Phases in the Catalytic Reduction of $\mathrm{NO}$ by $\mathrm{NH}_{3}$ Studied by in Situ Diffuse Reflectance FTIR Spectroscopy. J Catal., 1995, 157,312-320. 
16. Long R.Q.; Yang R.T.; Selective Catalytic Oxidation of Ammonia to Nitrogen over $\mathrm{Fe}_{2} \mathrm{O}_{3}-\mathrm{TiO}_{2}$ Prepared with a Sol-Gel Method, J Catal 2002, 207,158-165.

17. Kang, M.; Choi, J.; Kim, Y. T.; Park, E. D.; Shin, C. B.; Suh, D. J.; Yie, J. E.; Effects of preparation methods for $\mathrm{V}_{2} \mathrm{O}_{5}-\mathrm{TiO}_{2}$ aerogel catalysts on the selective catalytic reduction of $\mathrm{NO}$ with $\mathrm{NH}_{3}$ Korean J. Chem. Eng., 2009, 26(3), 884-889.

18. Abdullah, Z.; Abdullah, H. ; Bhatia, S. ; Salamatinia, B. ; Mootabadi, H.; Simple Kinetic Modeling of Selective Reduction of Nitric Oxide in Diesel Exhaust Over Cu-Zn/ ZSM-5 Monolithic Catalyst, Iran. J. Chem. Eng., 2010, 7, (3), 74-80.

19. Sultana, A.; Sasaki, M.; Suzuki, K.; Hamada, $\mathrm{H}$.; Tuning the NOx conversion of $\mathrm{Cu}-\mathrm{Fe} /$ ZSM-5 catalyst in NH 3-SCR, Catal. Commun. , 2013, 41, 21-25.

20. Hamidzadeh, M. ; Ghassemzadeh, M. ; Tarlani, A. ; Sahebdelfar, S. ; A Comparative Study of $\mathrm{M} / \mathrm{ZSM}-5$ (M= Pd, Ag, Cu, Ni) Catalysts in the Selective Reduction of Nitrogen (II) Oxide by Ammonia, IJSRST, 2015, 1 (1) 6-11.

21. Joshi, S.Y.; Kumar, A.; Luo, J.; Kamasamudram, K.; Currier, N. W.; Yezerets, A.; Combined experimental and kinetic modeling study of the bi-modal $\mathrm{NO} \times$ conversion profile on commercial Cu-SAPO-34 catalyst under standard SCR conditions, Appl. Catal. B., 2015, 165, 27-35.

22. Aly, H. M. ; Moustafa, M. E.; Abdelrahman, E. A. ; Effects of ultrasonic treatment on zeolite $\mathrm{NaA}$ synthesized from by-product silica, Der Chemica Sinica, 2011, 2 (4),166-173.

23. Vieira, S. S.; Magriotis, Z. M.; Ribeiro, M. F.; Graça, I.; Fernandes, A.; Manuel J.; Lopes , F.M. ; Coelho, S. M.; Santos, N. V.; Saczk , A. Ap.; Use of HZSM-5 modified with citric acid as acid heterogeneous catalyst for biodiesel production via esterification of oleic acid, Micropor. Mesopor. Mat. 2015, 201, 160-168.

24. Mohan, N.; Cindrella, L.; Direct synthesis of Fe-ZSM-5 zeolite and its prospects as efficient electrode material in methanol fuel cell, Mat. Sci. Semicon. Proc., 2015, 40, 361-368.

25. Mohamed, R.M.; Fouad, O.A.; Ismail, A.A.;
Ibrahim, I.A. ; Influence of crystallization times on the synthesis of nanosized ZSM-5, Mater. Lett. 2005, 59, 3441-3444.

26. Chang, Y. ; Jun, L.; Li, J.-S. ; Yang, Y.-C. ; Sun, $\mathrm{X} . \mathrm{Y}$. ; Preparation and characterization of nanosized ZSM-5 zeolites in the absence of organic template, Mater. Lett. 2005, 59 , 3427-3430

27. Karimi, R.; Bayati, B.; Aghdam, N. C.; Ejtemaee, M.; Babaluo, A. A.; Studies of the effect of synthesis parameters on ZSM-5 nano crystalline material during templatehydrothermal synthesis in the presence of chelating agent, Powder Technol. ,2012 , 229, 229-236.

28. Cheng, Y.; Liao, R.H.; Li , J.S.; Sun, X.Y.; Wang, L.J.; Synthesis research of nanosized ZSM-5 zeolites in the absence of organic template, J. Mat. Proc. Technol., 2008, 206, 445-452.

29. Thirupathi, B.; Smirniotis, P.G.; Co-doping a metal (Cr, Fe, Co, Ni, Cu, Zn, Ce, and $\mathrm{Zr}$ ) on $\mathrm{Mn} / \mathrm{TiO}_{2}$ catalyst and its effect on the selective reduction of $\mathrm{NO}$ with $\mathrm{NH}_{3}$ at low-temperatures Appl. Catal. B, 2011,110, 195-206.

30. Jung, S. M.; Demoulin, O.; Grange, P.; The study of a synergetic effect over a H-ZSM-5/ $\mathrm{V}_{2} \mathrm{O}_{5}$ hybrid catalyst on SCR reaction, J. Mol. Catal. A,, 2005, 236 (1-2), 94-98.

31. Ayari, F.; Mhamdi, M.; Álvarez-Rodríguez, J.; Guerrero Ruiz, A.R. ; Delahay, G. ; Ghorbel, A. ; Selective catalytic reduction of $\mathrm{NO}$ with $\mathrm{NH}_{3}$ over Cr-ZSM-5 catalysts: General characterization and catalysts screening, Appl. Catal. B, 2013, 134-135, 367-380.

32. López-Fonseca, R. ; de Rivas, B.; GutiérrezOrtiz, J.I.; Aranzabal, A.; González-Velasco, J.R. ; Enhanced activity of zeolites by chemical dealumination for chlorinated VOC abatement, Appl. Catal. B, 2003, 41, 31-42.

33. Karge, H.G. ; Characterization by infrared spectroscopy, Micro. Meso. Mater. ,1998, 22(4-6), 547-549.

34. Manigandan, R.; Giribabu, K.; Suresh, R.; Munusamy, S.; Praveen kumar, S.; Muthamizh, S.; Stephen A.; Narayanan, V.; Characterization and Photocatalytic activity of Nickel oxide nanoparticles. Int. J. Chemtech. Res. 2014, 6 (6), 3395-3398.

35. Ivanova, A. S.; Slavinskaya, E. M. ; Stonkus, O. 
A. ; Zaikovskii, V. I. ; Danilova, I. G. ; Gulyaev, R. V. ; Bulavchenko, O. A. ; Tsibulya, S. V. ; Boronin, A. I. ; Low-temperature oxidation of carbon monoxide over $\left(\mathrm{Mn}_{1 " x} \mathrm{M}_{x)} \mathrm{O}_{2}(\mathrm{M}=\right.$ Co, Pd) catalysts, Kinet. Catal., 2013, 54, (1) ,81-94.

36. Chmielarz, L.; Wegrzyn, A.; Wojciechowska, M.; Witkowski, S.; Michalik, M.; Selective catalytic oxidation (SCO) of ammonia to nitrogen over hydrotalcite originated $\mathrm{Mg}-\mathrm{Cu}-$ Fe mixed metal oxides Catal. Lett. 2011,141, 1345-1354.
37. Togashi, H.; Kojima, N.; Ban, T. ; Tsujikawa, I.; Optical Absorption by $\mathrm{Mn}^{2+}$ Ions in $\mathrm{MnM}$ (edta) $6 \mathrm{H}_{2} \mathrm{O}(\mathrm{M}=\mathrm{Zn}, \mathrm{Cu}, \mathrm{Ni}$, and $\mathrm{Co})$, Bull. Chem. Soc. Jpn. 1988, 61, 1903-1909.

38. Stevenson, S. A.; Vartuli J. C.; Brooks, C. F.; Kinetics of the selective catalytic reduction of NO over HZSM-5, J. Catal. 2000,190, 228-239.

39. Yamamoto, A.; Mizuno, Y.; Teramura, K.; Shishidoab, T.; Tanaka, T.; Effects of reaction temperature on the photocatalytic activity of photo-SCR of $\mathrm{NO}$ with $\mathrm{NH}_{3}$ over a $\mathrm{TiO}_{2}$ photocatalyst, Catal. Sci. Technol., 2013,3, 1771-1775. 